\title{
Miswak users' behavior model based on the theory of planned behavior in the country with the largest Muslim population
}

This article was published in the following Dove Press journal: Clinical, Cosmetic and Investigational Dentistry

\author{
Taufan Bramantoro' \\ Navilah Karimah ${ }^{2}$ \\ Agung Sosiawan' \\ Raden Darmawan Setijanto' \\ Titiek Berniyanti' \\ Retno Palupi' \\ Gilang Rasuna Sabdho \\ Wening' \\ 'Department of Dental Public \\ Health, Faculty of Dental Medicine, \\ Universitas Airlangga, Surabaya, \\ Indonesia; ${ }^{2}$ Dental Medicine \\ Program, Faculty of Dental Medicine, \\ Universitas Airlangga, Surabaya, \\ Indonesia
}

Background: Maintaining proper oral hygiene has an influence on oral health. Religious obedience may influence individual behavior. According to Islamic religious guidance, as recommended by an Islamic role model, it is obligated to maintain oral health and the recommended tool to use is miswak.

Purpose: To describe miswak users' behavior based on the theory of planned behavior.

Subjects and methods: The population of this study was the students of As-Salafi Al-Fitrah Islamic Boarding School who used miswak regularly and were healthy physically and mentally. One hundred and nine samples were chosen randomly and asked to complete a semi-open and a closed-ended questionnaire.

Results: Perceived behavioral control had the most dominant influence toward improving intention with $\beta=0.211$ and $p<0.05$. In contrast, attitude and subjective norms had less influence toward improving intention with $\beta=0.190$ and $p>0.05$, and $\beta=0.164$ and $p<0.0001$, respectively. Meanwhile, perceived behavioral control showed direct correlation toward action in model parameter with $\beta=0.445$ and $p<0.0001$.

Conclusion: Perceived behavioral control is the most dominant predisposing factor in increasing intention and attitude of miswak use.

Keywords: attitude, subjective norm, perceived behavioral control, intention, miswak use

\section{Introduction}

Individual oral health depends on one's behavior in maintaining oral hygiene. ${ }^{1-3}$ In order to maintain oral hygiene, individual awareness to keep oral hygiene regularly is required to build appropriate behavior in maintaining oral hygiene. Religious aspect is also involved in influencing the behavior of people, as individuals, groups, or even nations. ${ }^{3,4}$ Religious faith is one of the predisposing factors in improving attitudes, motivations, and behaviors. Islam, in terms of belief or cultures and values or norms of life, also encourages its followers to keep both themselves and the environment clean, including the guidance it provides to keeping oral hygiene using miswak. ${ }^{2,4}$

The Muslim role model persuades its followers to maintain dental health using miswak as a tool to clean the oral cavity, which aims to prevent dental and periodontal diseases and keep the oral cavity fresh. This history has created an impression that use of miswak has long been a tradition of cleaning the oral cavity in Islam. ${ }^{2}$ Miswak can be used to clean the oral cavity, which is believed to have more advantages than the common toothbrushes. ${ }^{5-8}$

Indonesia is known as a country with the largest Muslim population in the world, with a Muslim population of about $204,847,000$ in 2010 . Approximately $87.2 \%$ of
Correspondence: Taufan Bramantoro Department of Dental Public Health, Faculty of Dental Medicine, Universitas Airalngga, Jl. Mayjend Prof Dr Moestopo 47, 60132, Surabaya, Indonesia

Tel +62 31 5030255

Email taufan-b@fkg.unair.ac.id 
the Muslim population in the world lives in Indonesia. ${ }^{9,10}$ Therefore, our study was conducted in Indonesia. Meanwhile, As-Salafi Al-Fitrah Islamic Boarding School has students who come from all over Indonesia, so it can be considered to represent Muslims in Indonesia.

The use of miswak is basically an uncommon behavior in Indonesia; yet, the miswak users are still considerably high in number, especially in the Muslim community that has a strong belief to embrace the religion's guidance. Therefore, our study was intended to investigate the predisposing factors of miswak use by observing some aspects, such as the surrounding norms and one's belief to do something, which are part of the theory of planned behavior. Therefore, we considered to use the theory of planned behavior as the theory in this study.

The model used to assess behavior is one of the behavior theories that is commonly used in various disciplines, which constitutes suggested positive behavior (attitude), supported with subjective norms and perceived behavioral control, resulting in higher intention. ${ }^{1-13}$ According to the theory of planned behavior, intention is determined by the attitude, that is, favorable or unfavorable views of a behavior, subjective norm, that is, perceived social influence to perform a behavior, and perceived behavioral control, that is, the perception that the ability to perform a behavior is within individual control, all of which are interconnected. ${ }^{14}$ Each person has varying backgrounds that may affect the intention to do something. These differences exist depending on the different experiences and knowledge. ${ }^{14,15}$

Based on previous descriptions, it is necessary to investigate the miswak use behavior using the theory of planned behavior in the country with the largest Muslim population.

\section{Subjects and methods}

This study has been approved by the Health Research Ethical Commission with the certificate number 069/HRECC. FODM/VI/2017. All of the students in the boarding school were under the care of teachers as caregivers; therefore, on behalf of their parents, with the parents' approval, the teacher assisted the student to sign the consent form as approved by the Health Research Ethical Commission. The respondents were recruited from one of the largest boarding schools in Surabaya, named as As-Salafi Al-Fitrah Islamic Boarding School Surabaya, in which students come from various regions of Indonesia. The respondents were chosen by simple random sampling method, and the inclusion criteria were students who used miswak regularly, either combined with or without regular toothbrush, and were healthy physically and mentally, which was an indicator that the respondents were able to communicate well. One hundred and nine students were randomly selected as respondents. All respondents who participated in this study agreed to participate without receiving any compensations, by signing a consent form.

The respondents were asked to complete questionnaires with semi-open and closed-ended questions. Respondents' characteristics assessment used semi-open questions, while respondents' behavior assessment used closed-ended questions of miswak use based on the theory of planned behavior that consisted of attitudes, subjective norms, perceived behavioral controls, motivations, and miswak use behavior.

We analyzed the data using XLstat 2017 by XLstat. The data are shown in tables and the descriptive analysis in percentage and odds ratio (OR). The multivariate analysis was completed using linear regression.

\section{Results}

Most of the respondents were 15 years old (85\%). More than half were using both miswak and toothbrushes (56\%), and half of respondents started using miswak when they enrolled in the Islamic boarding school (51.33\%; Table 1). After getting better understanding of Islamic guidance, and supported by the surrounding community members who were all using miswak, they started using miswak without receiving any

Table I Miswak users' characteristics

\begin{tabular}{lll}
\hline Characteristics & $\mathbf{n}$ & $\%$ \\
\hline Age (years) & 13 & 11.93 \\
$\quad<15$ & 93 & 85.32 \\
I5-20 & 3 & 2.75 \\
$\quad>20$ & & \\
Miswak use & 48 & 44.04 \\
$\quad$ Miswak only & 61 & 55.96 \\
$\quad$ Combined & & \\
Miswak use period & 8 & 7.34 \\
Since childhood & 56 & 51.38 \\
Since enrollment & 32 & 29.36 \\
For a few years & 13 & 11.92 \\
For a few months & & \\
Place of purchase & 99 & 90.82 \\
Store near school & 9 & 8.26 \\
Store in Islamic community & 1 & 0.92 \\
Neighborhood & & \\
Way of use & 103 & 94.49 \\
Brushed teeth & 1 & 0.92 \\
Bit or chewed & 5 & 4.59 \\
Combined & & 7.34 \\
Shared miswak & 8 & 18.35 \\
Usually & 20 & 74.31 \\
Seldom & 81 & \\
Never & & \\
\hline
\end{tabular}


reward. Instead, they believed they will get reward from Allah subhanallahu wa ta'ala.

Most of the respondents had positive attitudes toward miswak use. About $87 \%$ respondents had positive attitude toward the statement "Miswak can help maintain oral hygiene and health," while the lowest attitude was toward the statement "Miswak has the ability to control oral bacteria growth" (67\%; Table 2).

Our study showed that the respondents' attitudes toward subjective norms affect the miswak use behavior, which also proved that most of the respondents had positive subjective norms toward miswak use. Most of the respondents agreed with the subjective norm statement "I use miswak as the incarnation of my faith" (87\%), while only $64 \%$ agreed to the subjective norm statement "My parents and family also use miswak."

The rates of respondents who agreed on perceived behavioral controls, intentions, and behaviors toward miswak use were compared. About $82 \%$ respondents had perceived behavioral controls toward cleansing teeth using miswak correctly, while $79 \%$ respondents had intention to do so and $83 \%$ believed they had cleansed their teeth using miswak correctly.
The most influencing attitude toward respondents' intentions of using miswak regularly was they believed miswak had benefits to maintain the oral hygiene and health. The respondents who agreed with the statement that miswak can maintain oral hygiene and health could raise intention 4.54 times more likely than the respondents who disagreed (OR 4.54).

Based on the subjective norms, the statement with the highest influence was "People around me advise me to use miswak." It showed that the respondents who agreed with this statement had an intention 3.36 times higher than the respondents who disagreed (OR 3.36).

The statement "I can use miswak regularly at least twice a day" had the highest impact on affecting the respondents' intention to use miswak. The respondents who agreed with the statement had 6.56 times higher intention than those who disagreed (OR 6.56).

The most influencing attitude toward intention was the statement "Miswak is the best alternative in maintaining oral hygiene." The respondents who agreed with the aforementioned statement had 6.27 times higher intention than those who disagreed (OR 6.27).

The statement about miswak use guidance had the highest influence toward the respondents' intention to cleansing the

Table 2 Frequency of attitudes, subjective norms, perceived behavioral controls, and intentions toward miswak use

\begin{tabular}{|c|c|c|c|c|}
\hline \multirow[t]{2}{*}{ Variables } & \multicolumn{2}{|c|}{ Agree } & \multicolumn{2}{|c|}{ Disagree } \\
\hline & $\mathbf{n}$ & $\%$ & $\mathbf{n}$ & $\%$ \\
\hline \multicolumn{5}{|l|}{ Attitudes toward miswak use } \\
\hline Oral health is as important as and is correlated to general health & 95 & 87.16 & 14 & 12.84 \\
\hline Miswak has the ability to control oral microbial growth & 73 & 66.97 & 36 & 33.03 \\
\hline Miswak helps maintain oral hygiene and health & 96 & 88.07 & 13 & 11.93 \\
\hline Miswak use for brushing teeth has the same result as using a toothbrush and toothpaste & 84 & 77.06 & 25 & 22.94 \\
\hline Miswak is the best alternative way to maintain oral health & 92 & 84.40 & 17 & 15.60 \\
\hline \multicolumn{5}{|l|}{ Subjective norms toward miswak use } \\
\hline My religion advises to use miswak & 92 & 84.40 & 17 & 15.60 \\
\hline I use miswak as the incarnation of my faith & 93 & 85.32 & 16 & 14.68 \\
\hline My community also uses miswak & 73 & 66.97 & 36 & 33.03 \\
\hline My community advises me to use miswak & 71 & 65.14 & 38 & 34.86 \\
\hline My parents and family also use miswak & 70 & 64.22 & 39 & 35.78 \\
\hline My parents and family advise me to use miswak & 7I & 65.14 & 38 & 34.86 \\
\hline \multicolumn{5}{|l|}{ Perceived behavioral controls toward miswak use } \\
\hline I am able to use miswak at least twice a day & 72 & 66.06 & 37 & 33.94 \\
\hline I am able to clean my teeth using miswak correctly & 89 & 81.65 & 20 & 18.35 \\
\hline I am able to get miswak as a tool to clean my teeth & 88 & 80.73 & 21 & 19.27 \\
\hline \multicolumn{5}{|l|}{ Intentions toward miswak use } \\
\hline I will use miswak at least twice a day & 76 & 69.72 & 33 & 30.28 \\
\hline I will clean all of my teeth using miswak correctly & 86 & 78.90 & 23 & 21.10 \\
\hline I will always store miswak as a tool to clean my teeth & 82 & 75.23 & 27 & 24.77 \\
\hline \multicolumn{5}{|l|}{ Actions toward miswak use } \\
\hline I have been using miswak regularly & 81 & 74.31 & 28 & 25.69 \\
\hline I clean all my teeth appropriately using miswak & 90 & 82.57 & 19 & 17.43 \\
\hline I always provide miswak as a tool to clean my teeth & 87 & 79.82 & 22 & 20.18 \\
\hline
\end{tabular}


teeth using miswak correctly. The respondents who agreed with the statement "There is a guidance to use miswak according to my religion" had 1.71 times higher intention than those who disagreed (OR 1.71).

The highest influence of respondents' intention to clean their teeth appropriately using miswak was the statement "I am able to clean my teeth appropriately using miswak." Our study showed that the respondents who agreed with the statement had 3.29 times higher intention than those who disagreed.

The most influencing statement toward the respondents' intention to provide miswak was "Oral hygiene is as important and correlates to general health." The respondents who agreed with the statement had 2.64 times higher intention than those who disagreed (OR 2.64).

The highest influence toward intention was the statement "I use miswak as the incarnation of my faith." The respondents who agreed with the statement had 2.84 times higher intention than those who disagreed (OR 2.84).

The statement with the highest influence was "I am able to cleanse my teeth appropriately using miswak." Respondents who agreed with the statement had 4.24 times higher intention than those who disagreed (OR 4.24).

The most influencing statement on the action was about miswak using habit. The respondents who agreed with the statement of miswak use behavior had 2.14 times higher intention than those who disagreed (OR 2.14; Table 3).

Meanwhile, the action to use miswak correctly was mostly affected by the intention to provide miswak. The respondents who agreed with the statement "The intention to provide miswak could clean teeth using miswak correctly" had 6.36 times higher intention than those who disagreed (OR 6.36).

The action to provide miswak was mostly affected by the intention to cleanse teeth using miswak correctly. The respondents who agreed with the statement "The intention to clean the teeth using miswak correctly" had miswak use intention 4.74 times higher than those who disagreed (OR 4.74).

Intention was mostly influenced by perceived behavioral controls, which showed in a model parameter $\beta=0.211$ and $p<0.05$. Meanwhile, attitudes $(\beta=0.190$ and $p=0.05)$ and subjective norms $(\beta=0.164$ and $p>0.05)$ had no influence. Intention had a correlation to building behavior with $\beta=0.594$ and $p<0.0001$. Perceived behavioral controls were directly correlated to taking action with $\beta=0.445$ and $p<0.0001$ (Scheme 1).

Our analysis showed that the best result for mean and SD that described sample heterogeneity was the perceived behavioral control ( $9 \pm 1.62)$, while the highest SD was for attitudes $(15 \pm 2.23)$.

\section{Discussion}

Based on the theory of planned behavior, behavioral intention is influenced by attitude, subjective norm, and perceived behavioral control that are interconnected with each other. Each individual has diverse variables to be considered that motivate them to conduct some behaviors. These differences are due to different experiences and levels of knowledge. ${ }^{11}$ Attitude toward behavior is determined by belief of acquired consequences from conducting behaviors called behavioral belief, which is considered based on outcome evaluation. ${ }^{16}$

In this study, the respondents had fully understood the benefits of miswak; as shown in Table 4, attitudes toward miswak had an OR $>1$ and a linear regression $\beta$-value reaching 0.19 . This result is in accordance with the theory stating that attitude toward behavior is determined by behavioral belief. ${ }^{16}$ Positive attitude can be developed from knowing the benefits of miswak that it contains some minerals that could kill or inhibit the growth of bacteria, reduce plaque, prevent dental caries, and preserve gingiva better than conventional

Table 3 Cross tabulation between intentions toward actions of miswak use behavior, cleaning teeth appropriately using miswak, and miswak provision

\begin{tabular}{|c|c|c|c|c|c|c|c|c|c|c|c|c|c|c|c|c|c|}
\hline \multirow[b]{4}{*}{ Intentions } & & \multirow[b]{4}{*}{ Total } & \multicolumn{15}{|c|}{ Action } \\
\hline & & & \multicolumn{5}{|c|}{ Miswak use behavior } & \multicolumn{5}{|c|}{$\begin{array}{l}\text { Teeth cleansing using } \\
\text { miswak correctly }\end{array}$} & \multicolumn{5}{|c|}{ Miswak provision } \\
\hline & & & \multicolumn{2}{|c|}{ Agree } & \multicolumn{2}{|c|}{ Disagree } & \multirow[t]{2}{*}{ OR } & \multicolumn{2}{|c|}{ Agree } & \multicolumn{2}{|c|}{ Disagree } & \multirow[t]{2}{*}{ OR } & \multicolumn{2}{|c|}{ Agree } & \multicolumn{2}{|c|}{ Disagree } & \multirow[t]{2}{*}{ OR } \\
\hline & & & $\bar{n}$ & $\%$ & $\bar{n}$ & $\%$ & & $\bar{n}$ & $\%$ & $\bar{n}$ & $\%$ & & $\bar{n}$ & $\%$ & $\bar{n}$ & $\%$ & \\
\hline \multirow[t]{2}{*}{ Miswak use behavior } & Agree & 76 & 60 & 78.95 & 16 & 21.05 & 2.14 & 66 & 86.85 & 10 & 13.15 & 2.48 & 64 & 84.21 & 12 & 15.79 & 2.32 \\
\hline & Disagree & 33 & 21 & 63.63 & 12 & 36.37 & & 24 & 72.73 & 9 & 27.27 & & 23 & 69.70 & 10 & 30.30 & \\
\hline \multirow{2}{*}{$\begin{array}{l}\text { Cleaning teeth appropriately } \\
\text { using miswak }\end{array}$} & Agree & 86 & 65 & 75.59 & 21 & 24.41 & 1.35 & 72 & 83.72 & 14 & 16.28 & $\mathrm{I} .43$ & 74 & 86.04 & 12 & 13.96 & 4.74 \\
\hline & Disagree & 23 & 16 & 69.57 & 7 & 30.43 & & 18 & 78.27 & 5 & 21.73 & & 13 & 56.52 & 10 & 43.48 & \\
\hline \multirow[t]{2}{*}{ Miswak provision } & Agree & 82 & 62 & 75.60 & 20 & 24.40 & 1.31 & 74 & 90.24 & 8 & 09.76 & 6.36 & 71 & 86.59 & II & 13.41 & 4.44 \\
\hline & Disagree & 27 & 19 & 70.38 & 8 & 29.62 & & 16 & 59.25 & 11 & 40.75 & & 16 & 59.26 & II & 40.74 & \\
\hline
\end{tabular}

Abbreviation: OR, odds ratio. 


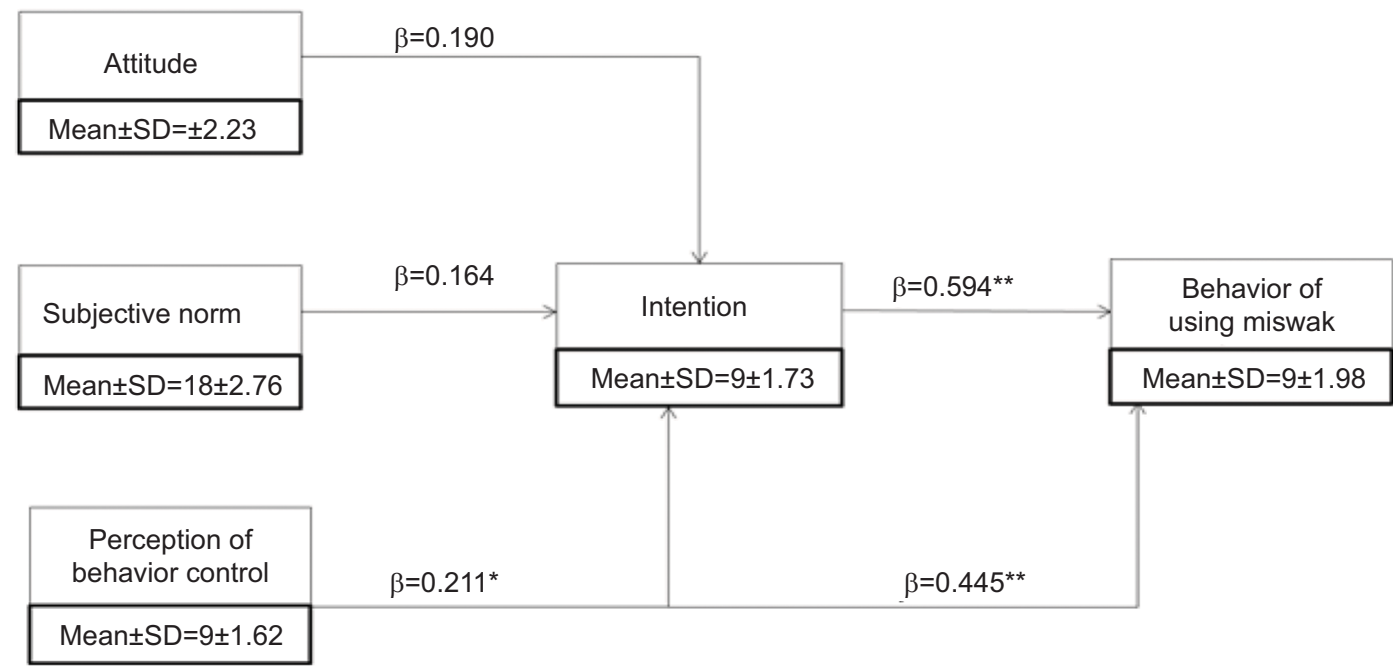

Scheme I Linear regression theory of planned behaviors on miswak users. *Linear regression parameter model, $p<0.05$; **linear regression parameter model $p<0.05$ $[<0.000 \mathrm{I}])$.

toothbrush and toothpaste. ${ }^{7,8,17-19}$ Some previous studies found that miswak has positive effects for oral health. Miswak has a high efficacy compared to using conventional toothbrush without toothpaste. Miswak can be used by cutting the stick to a length of $15 \mathrm{~cm}$ and then peeling the end top by $1 \mathrm{~cm}$. The tip of miswak should be rinsed in water before using. Miswak is then bitten and brushed directly from the gingival margin of the teeth on both buccal and lingual surfaces, so that it will clean all the teeth from plaque. Miswak has antibacterial effects on cariogenic microorganisms such as Streptococcus mutans and can support periodontal health by reducing dental plaque formation. Miswak also reduces the accumulation of Candida albicans, and thus may prevent oral candidiasis. ${ }^{20}$

The effect of attitudes toward miswak use behavior can be understood from the intention to cleanse the teeth using miswak correctly, which is mostly affected by the recognition of miswak as the best alternative way to maintain oral hygiene. The knowledge about miswak as a good alternative to maintain oral hygiene may improve the respondents' motivation to cleanse the teeth using miswak. An individual will have the intention to conduct a certain behavior when he/she has positive consideration. ${ }^{16}$

Subjective norms were also proved to have an effect toward the students' miswak use behavior. The subjective norms involved in this study were guidance from religion, communities, and parents. Religious guidance and faith incarnation as subjective norms that motivate an individual to use miswak were in accordance with the theory stating that religion may affect behavior, at an individual, a community, or a national level. Religion has strong influences on the behavior of its followers and is one of the important factors in a culture that may affect some aspects of life, such as values of life, attitudes, and habits. ${ }^{21-23}$

The effects of perceived behavioral control toward miswak use behavior could be seen from the intention to do it. Mostly, it was affected by perceived behavioral control that was shown by the behavior to use miswak twice a day regularly. The effect of perceived behavioral control as an important factor could also be observed from the intention to use miswak regularly, which was influenced by perceived behavioral controls as shown in the statement "I am able to clean my teeth properly using miswak." If someone believes he/she is capable of cleansing the teeth using miswak, he/she will tend to have intention to always use miswak as a tool to cleanse his/her teeth.

Perceived behavioral control toward miswak user behavior, not only showed the highest OR, but also recorded as the most dominant factor in increasing the miswak user intention. It not only has influence on taking action through intention, but also has direct influence without affecting the intention. Perceived behavioral control plays an important role in deciding an action.

Based on the data, it can be summarized that if an individual is assured to be able to use miswak regularly, he/she will have a greater tendency to build the intention of miswak use behavior. This result was in accordance with the definition of perceived behavioral control as someone belief toward factors that may facilitate or discourage; to be able to do or anticipate the obstacle to do something. ${ }^{16}$

Perceived behavioral control had an effect on increasing the intention to use miswak. This can be observed from the questionnaire results concerning perceived behavioral 
Table 4 Cross tabulation of behaviors, subjective norms, perceived behavioral controls toward intentions of using miswak, and cleaning teeth appropriately using miswak, and miswak provisions

\begin{tabular}{|c|c|c|c|c|c|c|c|c|c|c|c|c|c|c|c|c|c|}
\hline \multirow{4}{*}{\multicolumn{2}{|c|}{ Attitudes toward miswak use behaviors }} & \multirow{5}{*}{$\begin{array}{l}\text { Total } \\
95\end{array}$} & \multicolumn{5}{|c|}{ Miswak using behavior } & \multicolumn{5}{|c|}{$\begin{array}{l}\text { Cleaning teeth using } \\
\text { miswak appropriately }\end{array}$} & \multicolumn{5}{|c|}{ Miswak provision } \\
\hline & & & \multicolumn{4}{|c|}{ Intentions } & \multirow[t]{3}{*}{ OR } & \multicolumn{4}{|c|}{ Intentions } & \multirow[t]{3}{*}{ OR } & \multicolumn{4}{|c|}{ Intentions } & \multirow[t]{3}{*}{ OR } \\
\hline & & & \multicolumn{2}{|c|}{ Agree } & \multicolumn{2}{|c|}{ Disagree } & & \multicolumn{2}{|c|}{ Agree } & \multicolumn{2}{|c|}{ Disagree } & & \multicolumn{2}{|c|}{ Agree } & \multicolumn{2}{|c|}{ Disagree } & \\
\hline & & & $\bar{n}$ & $\%$ & $\bar{n}$ & $\%$ & & $\bar{n}$ & $\%$ & $\bar{n}$ & $\%$ & & $\bar{n}$ & $\%$ & $\bar{n}$ & $\%$ & \\
\hline Oral health is as important as and & Agree & & 69 & 72.63 & 26 & 27.37 & 2.65 & 77 & 81.05 & 18 & 18.95 & 2.38 & 74 & 77.90 & 21 & 22.10 & 2.64 \\
\hline correlates to general health & Disagree & 14 & 7 & 50.00 & 7 & 50.00 & & 9 & 64.29 & 5 & 35.71 & & 8 & 57.14 & 6 & 42.86 & \\
\hline Miswak is able to control oral & Agree & 73 & 52 & 71.23 & 21 & 28.77 & 1.24 & 58 & 79.45 & 15 & 20.55 & I.I & 58 & 79.45 & 15 & 20.55 & 1.93 \\
\hline bacterial growth & Disagree & 36 & 24 & 66.67 & 12 & 33.33 & & 28 & 77.78 & 8 & 22.22 & & 24 & 66.67 & 12 & 33.33 & \\
\hline Miswak helps maintaining oral & Agree & 96 & 71 & 73.96 & 25 & 26.04 & 4.54 & 75 & 78.13 & 21 & 21.87 & 0.65 & 73 & 76.04 & 23 & 23.96 & 1.41 \\
\hline hygiene and health & Disagree & 13 & 5 & 38.46 & 8 & 61.54 & & 11 & 84.62 & 2 & 15.38 & & 9 & 69.23 & 4 & 30.77 & \\
\hline Miswak use shows the same results & Agree & 84 & 57 & 67.86 & 27 & 32.14 & 0.67 & 68 & 80.95 & 16 & 19.05 & 1.65 & 66 & 78.57 & 18 & 21.43 & 2.06 \\
\hline as using a toothbrush and toothpaste & Disagree & 25 & 19 & 76.00 & 6 & 24.00 & & 18 & 72.00 & 7 & 28.00 & & 16 & 64.00 & 9 & 36.00 & \\
\hline Miswak constitutes the best & Agree & 92 & 67 & 72.83 & 25 & 27.17 & 2.38 & 78 & 84.78 & 14 & 15.22 & 6.27 & 71 & 77.17 & 21 & 22.83 & 1.84 \\
\hline $\begin{array}{l}\text { alternative for maintaining oral } \\
\text { health }\end{array}$ & Disagree & 17 & 9 & 52.94 & 8 & 47.06 & & 8 & 47.06 & 9 & 52.94 & & 11 & 64.71 & 6 & 35.29 & \\
\hline \multicolumn{18}{|c|}{ Subjective norms toward miswak use behaviors } \\
\hline There is a guidance to use miswak & Agree & 92 & 66 & 71.74 & 26 & 28.26 & 1.78 & 74 & 80.43 & 18 & 19.57 & 1.71 & 71 & 77.17 & 21 & 22.83 & 1.84 \\
\hline according to my religion & Disagree & 17 & 10 & 58.82 & 7 & 41.18 & & 12 & 70.59 & 5 & 29.41 & & 11 & 64.71 & 6 & 35.29 & \\
\hline I use miswak as an incarnation of & Agree & 93 & 66 & 70.97 & 27 & 29.03 & 1.47 & 74 & 79.57 & 19 & 20.43 & 1.30 & 73 & 78.49 & 20 & 21.51 & 2.84 \\
\hline my faith & Disagree & 16 & 10 & 62.50 & 6 & 37.50 & & 12 & 75.00 & 4 & 25.00 & & 9 & 56.25 & 7 & 43.75 & \\
\hline Community around me also uses & Agree & 73 & 55 & 75.34 & 18 & 24.66 & 2.18 & 58 & 79.45 & 15 & 20.55 & 1.10 & 53 & 72.60 & 20 & 27.40 & 0.64 \\
\hline miswak & Disagree & 36 & 21 & 58.33 & 15 & 41.67 & & 28 & 77.78 & 8 & 22.22 & & 29 & 80.56 & 7 & 19.44 & \\
\hline Community around me also advises & Agree & 71 & 56 & 78.87 & 15 & 21.13 & 3.36 & 58 & 81.69 & 13 & $|8.3|$ & 1.59 & 56 & 78.87 & 15 & 21.13 & 1.72 \\
\hline me to use miswak & Disagree & 38 & 20 & 52.63 & 18 & 47.37 & & 28 & 73.68 & 10 & 26.32 & & 26 & 68.42 & 12 & 31.58 & \\
\hline My parents and family also use & Agree & 70 & 55 & 78.57 & 15 & 21.43 & 3.14 & 55 & 78.57 & 15 & 21.43 & 0.95 & 54 & 77.14 & 16 & 22.86 & 1.33 \\
\hline miswak & Disagree & 39 & 21 & 53.85 & 18 & 46.15 & & 31 & 79.49 & 8 & 20.51 & & 28 & 71.79 & 11 & 28.21 & \\
\hline My parents and family advise me to & Agree & 71 & 54 & 76.06 & 17 & 23.94 & 2.31 & 55 & 77.46 & 16 & 22.54 & 0.78 & 56 & 78.87 & 15 & 21.13 & 1.72 \\
\hline use miswak & Disagree & 38 & 22 & 57.89 & 16 & 42.11 & & 31 & 81.58 & 7 & 18.42 & & 26 & 68.42 & 12 & 31.58 & \\
\hline \multicolumn{18}{|c|}{ Perceived behavioral control toward miswak use behavior } \\
\hline I am able to use miswak at least & Agree & 72 & 60 & 83.33 & 12 & 16.67 & 6.56 & 53 & 73.61 & 19 & 26.39 & 0.34 & 53 & 73.61 & 19 & 26.39 & 0.77 \\
\hline twice a day & Disagree & 37 & 16 & 43.24 & 21 & 56.76 & & 33 & 89.19 & 4 & 10.81 & & 29 & 78.38 & 8 & 21.62 & \\
\hline I am able to clean my teeth properly & Agree & 89 & 64 & 71.91 & 25 & 28.09 & 1.71 & 74 & 83.15 & 15 & 16.85 & 3.29 & 72 & 80.90 & 17 & 19.10 & 4.24 \\
\hline using miswak & Disagree & 20 & 12 & 60.00 & 8 & 40.00 & & 12 & 60.00 & 8 & 40.00 & & 10 & 50.00 & 10 & 50.00 & \\
\hline I am able to get miswak as a stock of & Agree & 88 & 65 & 73.86 & 23 & 26.14 & 2.57 & 72 & 81.82 & 16 & 18.18 & 2.25 & 67 & 76.14 & 21 & 23.86 & 1.28 \\
\hline teeth cleansers & Disagree & 21 & 11 & 52.38 & 10 & 47.62 & & 14 & 66.67 & 7 & 33.33 & & 15 & 71.43 & 6 & 28.57 & \\
\hline
\end{tabular}

Abbreviation: OR, odds ratio.

control, intention, and miswak use behavior, which were in accordance with miswak habits, cleansing teeth using miswak, and providing miswak as a tool to clean the oral cavity. The three variables had different effects on miswak use behavior. Perceived behavioral control had the most significant effect on intention and miswak use behavior, while both attitude and subjective norm had less effect on intention to use miswak. In addition, intention had a significant effect on miswak use behavior, which represented the seriousness of using miswak.

Intention is directly correlated to the miswak use behavior since it is mostly affected by the intention to use miswak regularly. Meanwhile, the intention to provide miswak had the highest influence on using miswak. This point describes that the more often the respondents provide miswak, the higher the possibility to use miswak. As for the intention to provide miswak, if the respondents cleanse their teeth using miswak, they will always provide miswak.

Intention is also affected by attitudes, subjective norms, and perceived behavioral controls that also influence the decision to have a certain behavior. ${ }^{16}$ Thus, this study is trying to find the correlation between attitudes, subjective norms, perceived behavioral controls, and their influence on the respondents' intention to favor a behavior, along with the correlation between intentions and actions.

In this study, the respondents' intentions on using miswak affect their decisions to use miswak. The results match with the theory stating that intention is assumed as a motivational factor that affects behavior. Intention constitutes the indicators of how much the effort is to conduct a behavior. 
Intention may predict the behavioral tendency. Intention is defined as the will to conduct a behavior. Intention is not constantly static but may change as time goes by. ${ }^{16}$

Based on the theory of planned behavior, the behavioral models of miswak users in the country with the largest Muslim population are affected by attitudes, subjective norms, perceived behavioral controls, and intentions of using miswak. This study focused on miswak users only because the psychosocial aspects of miswak users are not fully understood. Therefore, it is necessary to examine any further psychosocial factors that potentially affect a person to use miswak which is less common compared to using toothbrush. Against prior situation, this study focuses on individuals who use miswak regularly and not regularly. Unfortunately, this study is limited to miswak users in a limited community and does not analyze the method used by miswak users. Thus, further studies on a wider community are recommended.

\section{Conclusion}

Based on this study, it is concluded that perceived behavioral control constitutes the most dominant factor in increasing the intention and behavior of using miswak. Since miswak has been studied recently and has shown several benefits for oral health, such as antibacterial action and higher efficacy, compared to toothbrush, it can be used to complement toothbrush as recommended by Islamic religious guidance, or used as a supplementary only, as an effort to maintain oral health by adopting religious approach. Therefore, religious approach could be an effective approach to enhance positive oral health behavior in a community, especially in Islamic community.

\section{Acknowledgment}

The authors would like to show their gratitude to Universitas Airlangga for supporting this study.

\section{Author contributions}

TB, NK, AS, RDS, TiB, RP, and GRSW contributed to the design and implementation of the study, analysis of the results, writing of the manuscript, and agree to be accountable for all aspects of the work.

\section{Disclosure}

The authors report no conflicts of interest in this work.

\section{References}

1. Ryan LQ. Dental caries: a current understanding and implications. J Nat Sci. 2015;1(1):27.

2. Rahaju B. Tingkat keimanan islam dan status karies gigi santri. J Health Qual. 2014;5(1):1-66.
3. Sri W, Al Supartinah S, Yayi SP, Johana EP. Oral health status of elementary-school children varied according to school they attended. Dent J. (Majalah Kedokteran Gigi). 2016;49(3):163-167.

4. Taufan B, Yayi SP, Djauhar I, Udijanto T. The development of early childhood caries impact on quality of life-Indonesia instrument as assessment instrument of dental caries impact on quality of life of children aged 3-5 years based on Indonesian community characteristics. Dent J (Majalah Kedokteran Gigi). 2015;48(4):197-203.

5. Halawany HS. A review on miswak and its effect on various aspects of oral health. Saudi Dent J. 2012;24:63-69.

6. Poureslami HR, Makarem A, Mojab F. Paraclinical effects of miswak extract on dental plaque. Dent Re J. 2008;4:106-110.

7. Palombo EA. Traditional medicinal plant extracts and natural products with activity again oral bacteria: potential application in the prevention and treatment of oral diseases. Evid Based Complementary Altern Med. 2011;1:1-11.

8. Al-Bayati FA, Sulaiman KD. In vitro antimicrobial activity of salvadora persica 1. extracts against some isolated oral pathogens in Iraq. Turk $J$ Biol. 2008;32:57-62.

9. Houssain K. Muslim population in Asia: 1950-2020. Int J Environ Sci Dev. 2010;1(2):154-164.

10. Luis L, Alan C, Erin O, Sandra S. The future global muslim population projections for 2010-2030. Pew Res Center Forum Relig Pub Life. 2011;155-164.

11. Lee CB. Examining The Efficacy of The Theory of Planned Behavior (TPB) to Understand Pre-Service Teachers'Intention to Use Technology. Singapore: Nanyang Technology University;2010:968-972.

12. Zarina D, Akmal AO, Muhammad NII, Mohd FMK, Muhammad HH. The theory of planned behavior and self-identity factors drive graduates to be indebtedness. Int J Soc Sci Humani. 2015;5(4):343-346.

13. Irina Z, Liviu Z, Carmen BD, Carmen DB, Dumitrescuc AL. gender variation in phsycological faktor as defined by the teori of planned of oral hygiene behavior. J Procedia Soc Behav Sci. 2014;127: 353-357.

14. Ab Malik N, Mohamad Yatim S, Lam OLT, Jin L, McGrath C. Factors influencing the provision of oral hygiene care following stroke: an application of the theory of planned behaviour. Disabil Rehabil. 2018;40(8):889-893.

15. Lu HY, Hou HY, Dzwo TH, et al. Factors influencing intentions to take precautions to avoid consuming food containing dairy products: expanding the theory of planned behavior. Br Food J. 2010;112(9):919-933.

16. Ajzen I. Constructing a TpB questionnaire: conceptual and methodological considerations. TpB Questionnaire. 2006:1-14. Accessed January 11, 2017.

17. Sher H, Al-Yemeni MN, Wijaya L. Ethnobotanical and antibacterial potential of salvadora persica L: a well known medicinal plant in Arab and Unani system of medicine. J Med Plants Res. 2015;5:1224-1229.

18. Ezoddini-Ardakani F. Efficacy of miswak (salvadora persica) in preventing dental caries. Health J. 2010;2(5):499-503.

19. Al-Bayaty FH, Hamad A, AI-Koubaisi AH, Abdul N, Ali W, Abdulla MA. Effect of mouth wash extracted from salvadora persica (miswak) on dental plaque formation: a clinical trail. $J$ Med Plants Rese. 2010;4:1446-1454.

20. Sukkarwalla A, Ali SM, Lundberg P, Tanwir F. Efficacy of miswak on oral pathogens. Dent Res J. 2013;10:314-320.

21. Emily RL. Motivation: A Literature Review. Research Report. Pearson's Publication. 2011:4-36. Available from: https://images.pearsonassessments.com/images/tmrs/Motivation_Review_final.pdf. Accessed January 18, 2017.

22. Guay F, Chanal J, Ratelle CF, Marsh HW, Larose S, Boivin M. Intrinsic, identified, and controlled types of motivation for school subjects in elementary school children. Br J Educ Psychol. 2010;80(4):711-735.

23. Fatin NMN, Zubaidah AR, Monika MAR, Marina MB. The practice of using chewing stick (salvadora persica) in maintaining oral health: knowledge, perception and attitude of Malaysian Muslims adult. World Appl Sci J Innov Challenges Multidicipl Rese Pract. 2014;30: 351-359. 


\section{Publish your work in this journal}

Clinical, Cosmetic and Investigational Dentistry is an international, peer-reviewed, open access, online journal focusing on the latest clinical and experimental research in dentistry with specific emphasis on cosmetic interventions. Innovative developments in dental materials, techniques and devices that improve outcomes and patient satisfac- tion and preference will be highlighted. The manuscript management system is completely online and includes a very quick and fair peerreview system, which is all easy to use. Visit http://www.dovepress. com/testimonials.php to read real quotes from published authors.

Submit your manuscript here: https://www.dovepress.com/clinical-cosmetic-and-investigational-dentistry-journal 